\title{
Comparative Analysis of Signal Processing Techniques for Fault Detection in Three Phase Induction Motor
}

\author{
Thomas Amanuel \\ Graduate Assistant, \\ Mainefhi College of Engineering, \\ Asmara, Ministry of Education, Eritrea. \\ tomiasli123@gmail.com
}

\section{Amanuel Ghirmay, Huruy Ghebremeskel, Robel Ghebrehiwet \& Weldekidan Bahlibi \\ Mainefhi College of Engineering, Asmara, Eritrea.}

\begin{abstract}
Signal processing is considered as an efficient technique to detect the faults in threephase induction motors. Detection of different varieties of faults in the rotor of the motor are widely studied at the industrial level. To extend further, this research article presents the analysis on various signal processing techniques for fault detection in three-phase induction motor due to the damages in rotor bar. Usually, Fast Fourier Transform (FFT) and STFT are used to analyze the healthy and faulty motor conditions based on the signal characteristics. The proposed study covers the advantages and limitations of the proposed wavelet transform (WT) and each technique for detecting the broken bar of induction motors. The good frequency information can be collected from FFT techniques for handling multiple faults identification in three-phase induction motor. Despite the hype, the detection accuracy gets reduced during the dynamic condition of the machine because the frequency information on sudden time changes cannot be employed by FFT. The WT method signal analysis is compared with FFT to propose fault detection method for induction motor. The WT method is proving better accuracy when compared to all existing methods for signal information analysis. The proposed research work has simulated the proposed method with MATLAB / SIMULINK and it helps to effectively detect the healthy and faulty conditions of the motor.
\end{abstract}


Journal of Electronics and Informatics (2021)

Vol.03/ No.01

Pages: 61-76

https://www.irojournals.com/iroei/

DOI: https://doi.org/10.36548/jei.2021.1.006

Keywords: Induction Motor, STFT, Matlab / Simulink, Current Signature Analysis, Power Supply Imbalance, Single Phasing, Broken Rotor Bar.

\section{INTRODUCTION}

The three-phase induction motor is used in many industrial processes for their needs. It works in various conditions such as high temperature, electromagnetic signal interference, the noisy environment for both signal and physical impairments, vibration nearby machines, and environment stress, which can easily damage the internal parts of the motor [1]. Breakdown maintenance, continuous maintenance, and condition-based maintenance are the three types of maintenance involved in any electrical motors. Maintenance action taken on the defected motor is called as breakdown maintenance. The motor that gets maintenance for a long time before break down is called as continuous maintenance [2]. Also, when the experts are called off for inspection after break down is known as condition-based maintenance [3]. Figure 1 shows the types of fault detection techniques in a three-phase induction motor.

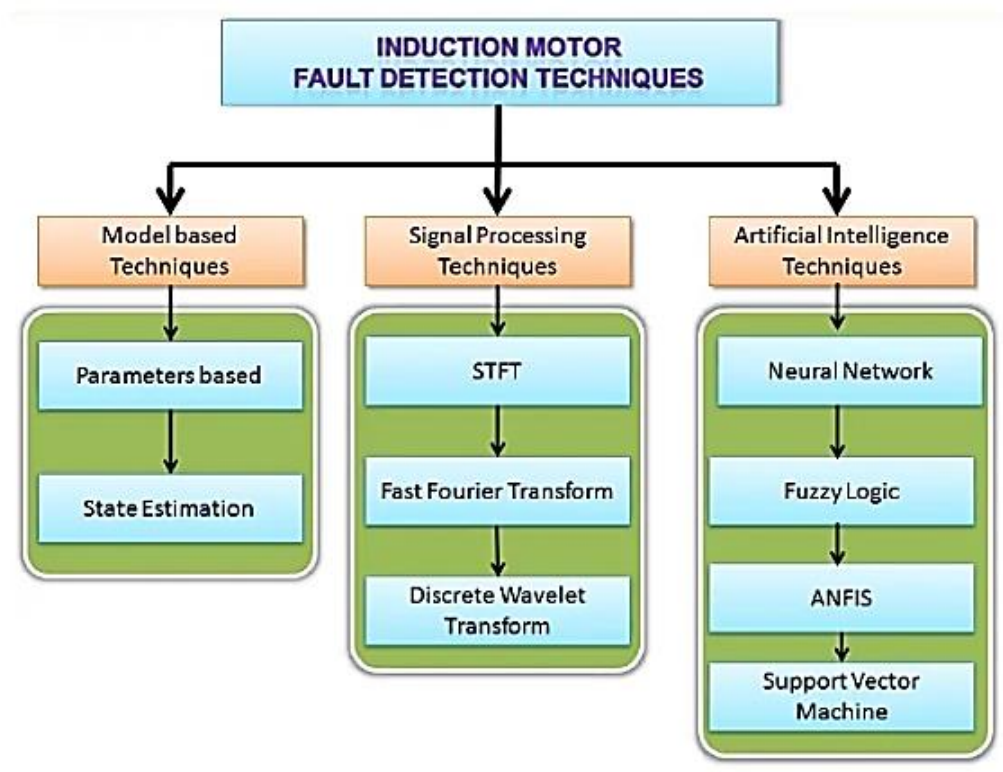

Figure 1 Types of Fault detection Techniques

The monitoring of the machine should be optimized to minimize the motor downtime. The advantages of condition-based monitoring are as follows; 
Journal of Electronics and Informatics (2021)

Vol.03/ No.01

Pages: 61-76

https://www.irojournals.com/iroei/

DOI: https://doi.org/10.36548/jei.2021.1.006

1. Motor failure can be predicted earlier.

2. The maintenance of the motor will be optimized.

3. The maintenance cost for the motor is reduced.

4. The productivity will be increased with less downtime for the machine.

5. The reliability of the motor increases.

When a defect is identified, a sufficient data is required for the plant operator on the correct dimension of the process [4] [5] [6]. If the details of the data are insufficient, the wrong fault diagnosis will affect the production of the whole management system. The experts can take the action against preventive maintenance and can arrange the necessary parts for repair. If it is required to minimize the motor downtime, obviously the productivity can be increased [7]. The frequency-domain analysis, time-domain analysis, and multi resolution analysis are used to find the fault detection of the machine.

The condition monitoring and fault detection in an induction motor require some current signals from the machine to study the behaviour [8] [9] [10]. Many techniques are proposed so far and their advantages and limitations are discussed.

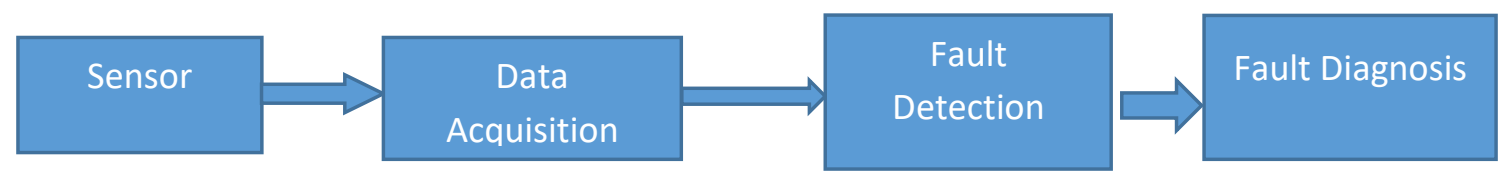

Figure 2 typical on line condition monitoring system process

This type of continuous evaluation of the machine is used to detect or monitor the regular faults with the operating characteristics of the machine. This could detect the faults early and diagnose the problem that occur in the machine during breakdown [11] [12]. An electrical device such as induction motors, generators, and transformers, etc. in power plants include four main parts for system detection or monitoring. The online condition monitoring system consists of sensors, data acquisition, and fault detection and diagnosis section shown in figure 2 . 
Journal of Electronics and Informatics (2021)

Vol.03/ No.01

Pages: 61-76

https://www.irojournals.com/iroei/

DOI: https://doi.org/10.36548/jei.2021.1.006

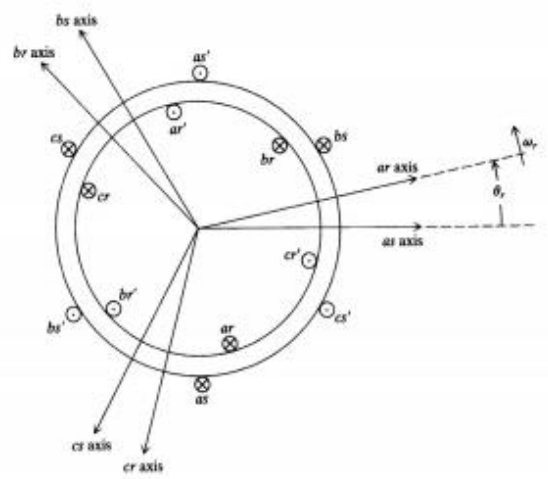

Figure 3 Basic Structure of Induction Machine Model

Figure 3 shows the basic structure of the induction motor model. The STFT is used to analyze the signal from the motor through the output lead [13]. Received signals are timedomain signal and it gets converted into frequency domain concept by the transformation, which is used to analyze the signal with fundamental frequency and harmonic components [14] [15] [16] [17].

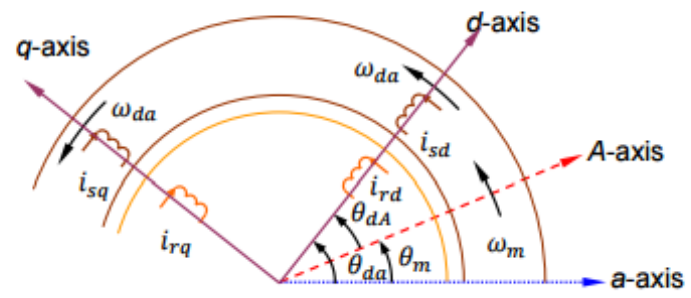

Figure 4 q-d Representation of Stator and Rotor Winding of Induction Motor

This transformation analysis of the induction motor transient characteristics with fixed window method is used for signal analysis. Figure 4 shows the q-d representation of stator and rotor winding setup of induction motor. The representation of "q" and " $d$ " are quadrature axis frames and direct axis frames [17] [18]. 
Journal of Electronics and Informatics (2021)

Vol.03/ No.01

Pages: 61-76

https://www.irojournals.com/iroei/

DOI: https://doi.org/10.36548/jei.2021.1.006

\section{ORGANIZATION OF THE RESEARCH}

The content of this research article is organized as follows; a related literature survey of signal processing techniques based on the detection methods used for induction motor in section 3. Further, Section 4 provides the mathematical derivation of the proposed wavelet transform for further analysis and synthesis filter construction. Section 5 shows the obtained resultant images and graphs. Section 6 presents the conclusion and future enhancement of the research work.

\section{PRELIMINARIES}

Refaat S.S et al proposed the detection techniques in stator-based problems for unbalanced supply in three phases. This method is incorporated with FFT current components of three-phase line and phase details for various failure types in an induction motor. The neural network approach is also proposed and proved the better efficiency of unbalance line supply. The artificial neural network (ANN) is more significant for fault detection in an induction motor [19]. Mehala et al proposed a motor current signature analysis for fault detection in an induction motor. They include the stator winding problems, rotor bar hole problem, and bearing control degradation [20]. Dash et al introduced the process fault diagnosis (PFD), which is used to diagnose the process flow with past and present sensor reading of the induction motor. They conclude that, the early diagnosis is a better solution than fault detection in an induction motor. Also, they proved better productivity based on the early diagnosis process event. The abnormal condition in any induction motor can discharge from the defect frequently [21].

The fault detection in the air gap is challenging by using the torque monitored method. The non-zero frequency can describe the fault condition of the machinery. The fault signature method is facing difficulty in upgrading the mathematical model [22]. The stator-related problems are imbalance in the supply and phase voltage under many conditions, which are overvoltage, single-phase problems, short circuit in windings, etc. [23]. Identifying various faults in induction motor and categorizing the faulty or healthy condition machinery is diagnosed by using certain parameters like vibration, torque, flux, and thermal condition of the machine [24]. 
Journal of Electronics and Informatics (2021)

Vol.03/ No.01

Pages: 61-76

https://www.irojournals.com/iroei/

DOI: https://doi.org/10.36548/jei.2021.1.006

\section{METHODOLOGIES}

\subsection{FFT approach}

Generally, the FFT method is faster than DWT based on computation power in multiplication and addition between the signal samples. $\mathrm{N}$ is determining the number of multiplication and addition. Therefore, the process will be faster than DWT in signal analysis. FFT decomposes the set of detailed signal spectrum values from one domain to another domain. Each stage process consist of the signal spectrum that can be processed with a small set of data and determine the variation of the dataset [25]. This variation by the FFT algorithm can be used to detect faults in induction motors. The FFT is defined as,

$$
X(k)=\sum_{n=0}^{N-1} x(n) e^{-j 2 \pi n k / N}
$$

And for FFT:

$$
\begin{aligned}
& X(k)=\sum_{n=0}^{N-1} x(n) W_{N}^{k n} \\
& W_{N}=e^{-j 2 \pi / N} \text { is twiddle factor; where } N=\text { no of data samples } \\
& K=0,1,2 \ldots \ldots N-1 \\
& x(n)=\text { time domain discrete signal. }
\end{aligned}
$$

Each frequency line is computed by the FFT function in a complex form such as real and imaginary form. The magnitude, phase, and power spectrum of the signal can be calculated for both healthy and faulty conditions of the induction motor [26].

$$
\begin{gathered}
M a g==\left(\sqrt{\operatorname{real}[\mathrm{FFT}(\mathrm{A})]^{2}+\operatorname{imag}[\mathrm{FFT}(\mathrm{A})]^{\wedge} 2}\right. \\
\text { Phase }=\arctan \left\{\frac{\operatorname{image}(F F T(A))}{\operatorname{Real}(F F T(A))}\right\} \\
\text { Power spectrum }=\left(F F T(A) * F F T^{*}(A)\right) / N
\end{gathered}
$$

The significant approach is incorporated in the stationary signal process. The diagnosis process should be an ensemble for both stationary and non-stationary processes of the machine. 
Journal of Electronics and Informatics (2021)

Vol.03/ No.01

Pages: 61-76

https://www.irojournals.com/iroei/

DOI: https://doi.org/10.36548/jei.2021.1.006

\subsection{Proposing Wavelet Transform Approach}

This transform approach is used to convert the signal from the time domain to frequency domain analysis. The window-based analysis is used to find any variation in signals throughout the signal spectrum.

\section{Step 1:}

The window, which is a size smaller than the time resolution will be better when compared to the larger size of the window. Discrete wavelet transform is calculated as follows;

$$
\begin{aligned}
& \mathrm{X}_{\text {DWT }}(\mathrm{k}, \mathrm{l})=\mathrm{a}^{-\mathrm{k} / 2} \int_{-\infty}^{\infty} \mathrm{x}(\mathrm{t}) \mathrm{h}\left(\mathrm{a}^{-\mathrm{k}} \mathrm{t}-l \mathrm{~T}\right) \mathrm{dt} \\
& \mathrm{X}(\mathrm{t})=\sum_{\mathrm{k}} \sum_{l} \mathrm{X}_{\text {DWT }}(\mathrm{k}, \mathrm{l})\left[\mathrm{a}^{-\mathrm{k} / 2} \mathrm{f}\left(\mathrm{a}^{-\mathrm{k}} \mathrm{t}-l \mathrm{~T}\right)\right. \\
& \text { Where: } \quad \mathrm{T}=1
\end{aligned}
$$

\section{Step 2:}

The filter construction is based on the parameters $\mathrm{k}$ and $\mathrm{l}$, which will generate the data spectrum for basic function with a variation of wavelets. By varying these $\mathrm{k}$ and 1 parameters, we can achieve the multi-channel multi-resolution approach in analysis and synthesis filters as follows;

Analysis filter:

$$
h_{k}(\mathrm{t})=\mathrm{a}^{-\mathrm{k} / 2} \mathrm{~h}\left(\mathrm{a}^{\left.-\mathrm{k}_{\mathrm{t}}\right)}\right.
$$

Synthesis filters:

$$
f_{k}(\mathrm{t})=\mathrm{a}^{-\mathrm{k} / 2} \mathrm{f}\left(\mathrm{a}^{-\mathrm{k}} \mathrm{t}\right)
$$

Functions $h(t)$ and $f(t)$ are derived by dilation of a single filter. Thus, the basic functions are dilated $\left(\mathrm{t}->\mathrm{a}^{-\mathrm{k}_{\mathrm{t}}}\right)$ and shifted $\left(\mathrm{t}->\mathrm{a}^{\left.-\mathrm{k}_{\mathrm{t}}\right)}\right.$ version of:

$$
\mathrm{f}(\mathrm{t})=\varphi_{k l}(\mathrm{t})=\mathrm{a}^{-\mathrm{k} / 2} \varphi\left(\mathrm{a}^{-\mathrm{k}} \mathrm{t}-\mathrm{lT}\right) \quad \mathrm{a} \text { is scaling parameter }
$$

Synthesis filter for perfect reconstruction:

$$
f_{k}(\mathrm{t})=h_{k} *(-\mathrm{t})
$$


Journal of Electronics and Informatics (2021)

Vol.03/ No.01

Pages: 61-76

https://www.irojournals.com/iroei/

DOI: https://doi.org/10.36548/jei.2021.1.006

\section{Step 3:}

The features can be extracted by DWT with half sampling rate frequency of $\frac{f_{\max }}{2}$ instead of $f_{\text {max }}$. The one level wavelet decomposition can be constructed by,

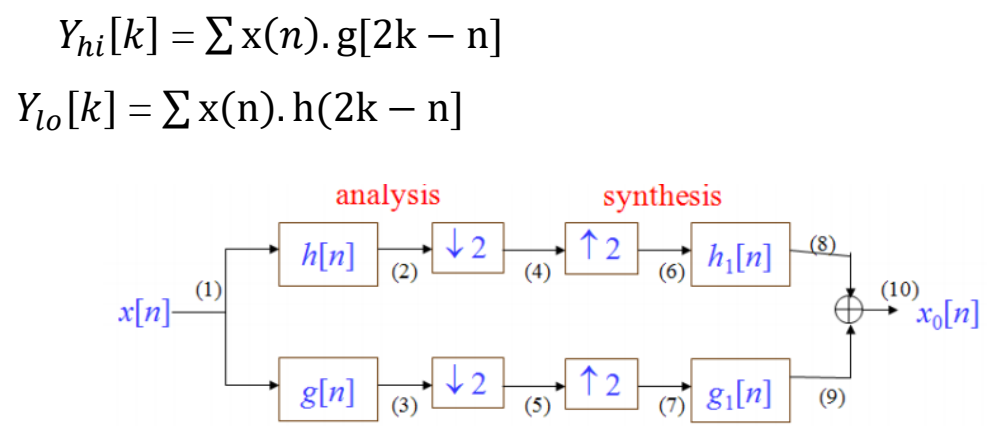

Figure 5 Block diagram of analysis and synthesis filter bank with sampling

\section{$\underline{\text { Step } 4}$}

The three-phase concentric windings that are incorporated in the stator are written as vectormatrix form since wavelet transform analysis is used for signal spectrum.

$$
\left[V_{s}\right]=\left[R_{s}\right]\left[I_{s}\right]+\frac{d}{d t}\left[\psi_{s}\right]
$$

Where:

$$
\begin{aligned}
{\left[I_{s}\right] } & =\left[I_{s a} ; I_{s b} ; I_{s c}\right] \\
{\left[\psi_{s}\right] } & =\left[L_{s s}\right]\left[I_{s}\right]+\left[L_{s r}\right]\left[I_{r}\right]
\end{aligned}
$$

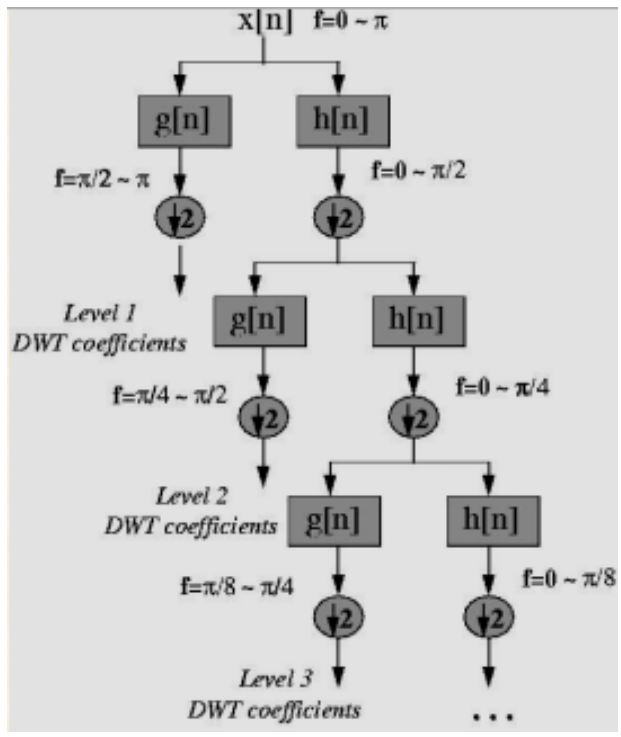

Figure 6 Decomposition of Signal into Details and Approximations 
Journal of Electronics and Informatics (2021)

Vol.03/ No.01

Pages: 61-76

https://www.irojournals.com/iroei/

DOI: https://doi.org/10.36548/jei.2021.1.006

The matrix $\left[R_{s}\right]$ is a $3 \times 3$ diagonal matrix, which consists of resistances of each coil.

$$
\begin{gathered}
{\left[\boldsymbol{R}_{\boldsymbol{s}}\right]=\left[\begin{array}{ccc}
R_{s} & 0 & 0 \\
0 & R_{s} & 0 \\
0 & 0 & R_{s}
\end{array}\right]} \\
{\left[\boldsymbol{L}_{s s}\right]=\left[\begin{array}{ccc}
L_{s a} & L_{s a b} & L_{s a c} \\
L_{s b a} & L_{s b} & L_{s b c} \\
L_{s c a} & L_{s c b} & L_{s c}
\end{array}\right]}
\end{gathered}
$$

Where:

$$
L_{s a}=L_{s a l}+L_{m s a}
$$

$L_{m s a}$ is the leakage inductance of a stator phase; $L_{m s a}=L_{s a b}+L_{s a c}$

$L_{s a l}$ is the self-inductance of the phase "a".

$L_{m s a}$ is the leakage inductance of a stator phase.

$L_{s a b}=L_{s a c}$ is the mutual inductance between two stator phases "a" and "b or c" for healthy(symmetrical) machine.

\section{Step 5:}

The energy conservation provides the symmetry matrices and mutual inductance matrix between the stator and rotor loops.

$$
\left[\boldsymbol{L}_{\boldsymbol{s r}}\right]=\left[\boldsymbol{L}_{\boldsymbol{r} s}\right]^{T}=\left[\begin{array}{lllll}
L_{s r 11} & L_{s r 12} & \ldots \ldots & L_{s r 1 n} & L_{s r 1 e} \\
L_{s r 21} & L_{s r 22} & \ldots \ldots & L_{s r 2 n} & L_{s r 2 e} \\
L_{s r 31} & L_{s r 32} & \ldots \ldots & L_{s r 3 n} & L_{s r 3 e}
\end{array}\right]
$$

\section{Step 6:}

The rotor loops voltage equations written in vector matrix form are as follows;

$$
\left[V_{r}\right]=\left[R_{r}\right]\left[I_{r}\right]+\frac{d}{d t}\left[\Psi_{r}\right]
$$

Where:

$$
\begin{aligned}
& {\left[V_{r}\right]=\left[\begin{array}{llllll}
V_{r 1} & V_{r 2} & \ldots & \ldots & V_{r n} & V_{r e}
\end{array}\right]^{T}} \\
& {\left[I_{r}\right]=\left[I_{r 1} ; I_{r 2} ; I_{r 3} ; \ldots \ldots \ldots ; I_{r n} ; I_{r e}\right]}
\end{aligned}
$$


Journal of Electronics and Informatics (2021)

Vol.03/ No.01

Pages: 61-76

https://www.irojournals.com/iroei/

DOI: https://doi.org/10.36548/jei.2021.1.006

\section{Correctness:}

In case of a cage rotor, the rotor end ring voltage is $\boldsymbol{V}_{\boldsymbol{r} \boldsymbol{e}}=\mathbf{0}$, and the rotor loop voltages are $V_{r k}=$ $0,(k=1,2, \ldots \ldots n)$.

Table 1 Nomenclature in Mathematical derivation for proposed algorithm

\begin{tabular}{|c|c|}
\hline$V_{s}=\left[\begin{array}{lll}V_{s a} & V_{s b} & V_{s c}\end{array}\right]$ & Stator's three phase voltages (V). \\
\hline$V_{r}=\left[\begin{array}{llllll}V_{r 1} & V_{r 2} & \ldots & \ldots & V_{r n} & V_{r e}\end{array}\right]$ & Rotor's three phase voltages (V). \\
\hline$I_{r}=\left[\begin{array}{llllll}I_{r 1} & I_{r 2} & \ldots & \ldots & I_{r n} & I_{r e}\end{array}\right]^{T}$ & Rotor's three phase currents (A). \\
\hline$I_{s}=\left[\begin{array}{lll}I_{s a} & I_{s b} & I_{s c}\end{array}\right]$ & Stator's three phase currents (A). \\
\hline$R_{s a}, R_{s b}, R_{s c}$ & Resistance of stator's winding per phases (Ohm). \\
\hline$R_{e}$ & Resistance of rotor end-ring (Ohm). \\
\hline$R_{b}$ & Resistance of rotor bar (Ohm) \\
\hline$L_{s l}, L_{r l}$ & Stator's and rotor's self-inductances (Henry) \\
\hline$L_{m}$ & Mutual inductance (Henry) \\
\hline$\omega_{r}$ & Rotor's angular speed (rad/sec) \\
\hline$\omega_{r m}$ & Rotor's speed (mechanical) (rad/sec) \\
\hline$\omega_{s}$ & Supply angular frequency (rad/sec) \\
\hline$\psi_{s,} \psi_{r}$ & Stator's and Rotor's fluxes (Weber) \\
\hline$\Theta$ & Angular position in the frame of motor (Deg) \\
\hline$\theta_{r}$ & $\begin{array}{l}\text { Angle between rotor's phase axis and stator's phase } \\
\text { axis }\end{array}$ \\
\hline
\end{tabular}

\section{RESULTS DISCUSSION}

STFT is performed with hamming, Bartlett, Blackman, and Chebyshev filter window with 256 samples. The window response in the frequency domain provides a better resolution than the time domain concept [26]. This window performing analysis increases the resolution in the frequency domain. The analysis of the signal from induction motors through wavelet transform can be completed with various wavelets (Daubechies, symlets). It is used to decompose the current signal at various levels with approximated analysis and synthesis coefficients. 
Journal of Electronics and Informatics (2021)

Vol.03/ No.01

Pages: 61-76

https://www.irojournals.com/iroei/

DOI: https://doi.org/10.36548/jei.2021.1.006

Table 2 Broken bar detection analysis conditions in induction motor

\begin{tabular}{|l|c|c|c|c|c|}
\hline \multirow{2}{*}{$\begin{array}{l}\text { Signal } \\
\text { processing } \\
\text { Techniques }\end{array}$} & \multicolumn{5}{|c|}{ Analysis Conditions } \\
\cline { 2 - 6 } & $\begin{array}{c}\text { No-load } \\
\text { Operation }\end{array}$ & $\begin{array}{c}\text { Full-Load } \\
\text { Operation }\end{array}$ & $\begin{array}{c}\text { Transient } \\
\text { signals }\end{array}$ & $\begin{array}{c}\text { Steady state } \\
\text { condition }\end{array}$ & $\begin{array}{c}\text { Torque } \\
\text { oscillation }\end{array}$ \\
\hline STFT & - & yes & yes & yes & - \\
\hline FFT & - & yes & - & yes & - \\
\hline Proposing WT & yes & yes & yes & yes & yes \\
\hline
\end{tabular}

Besides that Daubechies 44 and symlet 20 performs similar characteristics of our fault detection scenario. Figure 7 a shows a healthy motor graph and b shows a faulty motor. However, the selection of a wavelet is very appropriate, which leads to good detection accuracy in the faulty induction motor [27]. In addition to that, the level of analysis and synthesis is analyzed during the decomposition of the wavelet.
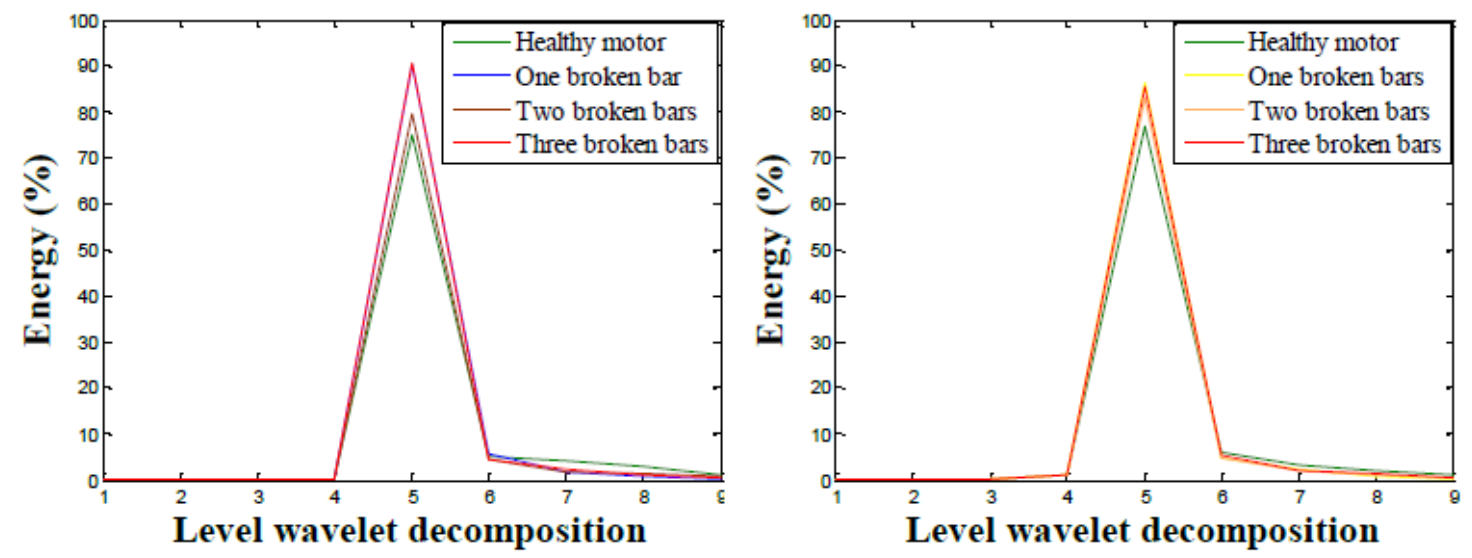

Figure 7 Energy co-efficient decomposition of current signal by wavelets for healthy and faulty motor (Daubechies 44 and symlet 20)

Figure 8-11 shows the signal spectrum of stator current one broken bar, stator current, speed measurement one broken bar and spectrum of one broken bar respectively. 


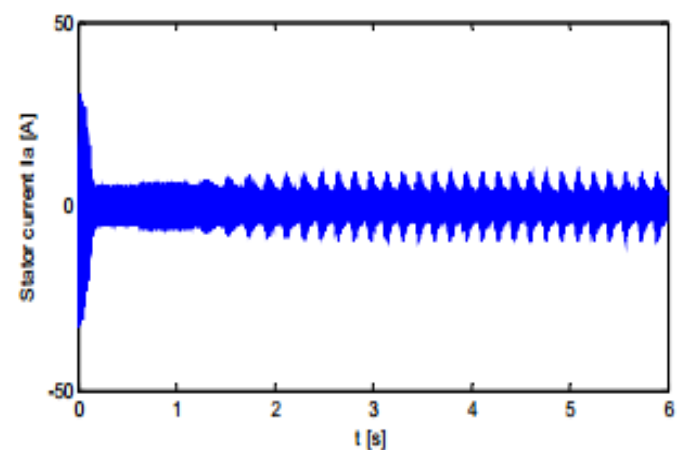

Figure 8 stator current for one broken bar

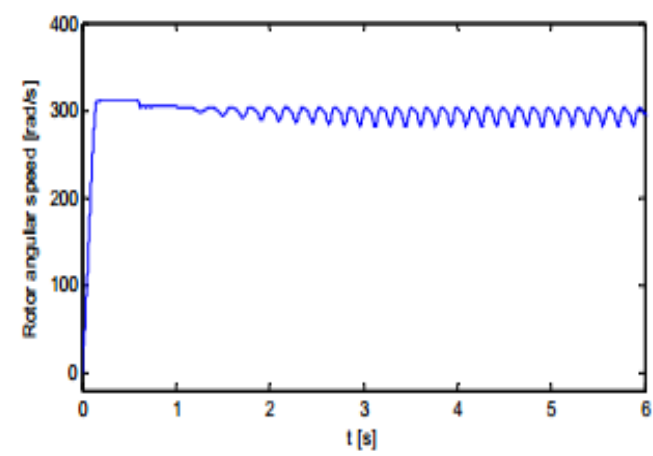

Figure 10 speed for one broken bar

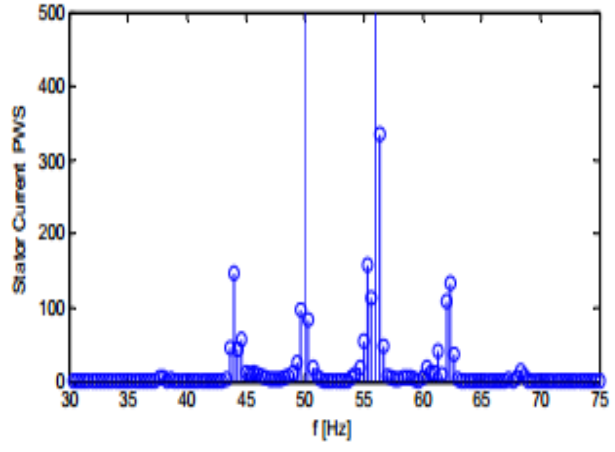

Figure 9 spectrum of stator current for broken bar

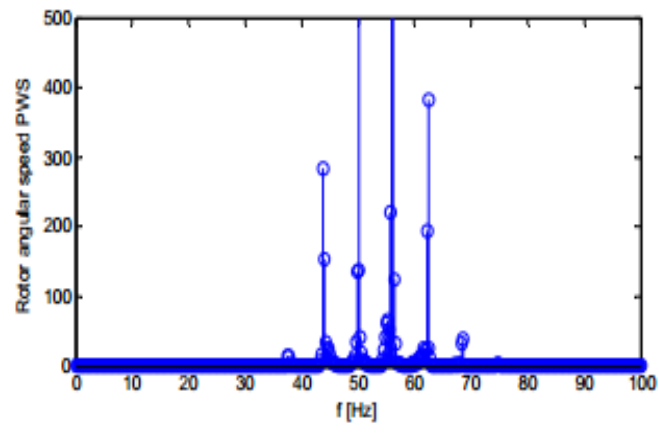

Figure 11 spectrum of speed for one broken bar

Table 2 summarizes the signal processing techniques with the obtained experimental results for broken bar detection in a three-phase induction motor. The table realizes that, the proposing wavelet transform performs in all condition with the ability to detect the faults in three-phase induction motor.

\section{CONCLUSION}

Thus, the proposed wavelet transform method is proving that detection accuracy is high when compared to the existing algorithms by including the FFT algorithm. The fault detection is based on the proposed wavelet transform, which detects the rotor broken bars fault easily. The other FFT algorithm is compared with the details of wavelet transform signal spectrum. The proposed method is used to identify the failure in a three-phase induction motor through the time 
Journal of Electronics and Informatics (2021)

Vol.03/ No.01

Pages: 61-76

https://www.irojournals.com/iroei/

DOI: https://doi.org/10.36548/jei.2021.1.006

sliding window in order to examine the motor signals. The proposed method is enhanced with the following features;

1. Motor speed control techniques may also get integrated into FPGA based system, which is used to detect the faults.

2. A generalized machine fault for the diagnostic system may be developed based on FFT and wavelet to be used with different types of motors and generators.

3. The present work in condition monitoring gets connected to the detection of faults in induction motors which are fed from the main supply directly. Inverter-driven machines are now becoming more extensively used in industries. There is a need to work on the detection of faults in inverter-driven motors.

The diagnostic of power quality problems that are related to motor supply may be incorporated into the system.

\section{REFERENCES}

[1] P. Karvelis, G. Georgoulas, I. P. Tsoumas, J. A. Antonino-Daviu, V. ClimenteAlarcon, and

C. D. Stylios, "A Symbolic Representation Approach for the Diagnosis of Broken Rotor Bars in Induction Motors," IEEE Trans. Ind. Informatics, vol. 11, no. 5, pp. 1028-1037, Oct. 2015.

[2] T. Yang, H. Pen, Z. Wang, and C. S. Chang, "Feature Knowledge Based Fault Detection of Induction Motors Through the Analysis of Stator Current Data," IEEE Trans. Instrum. Meas., vol. 65, no. 3, pp. 549-558, Mar. 2016

[3] J. Chen, Z. Li, J. Pan, G. Chen, Y. Zi, J. Yuan, B. Chen, and Z. He, "Wavelet transform based on inner product in fault diagnosis of rotating machinery: A review," Mech. Syst. Signal Process., vol. 70-71, pp. 1-35, Mar. 2016.

[4] A. Sapena-Bano, M. Pineda-Sanchez, R. Puche-Panadero, J. Martinez-Roman, and D. Matic, "Fault Diagnosis of Rotating Electrical Machines in Transient Regime Using a Granda, ArcosAviles \& Sotomayor. Analysis of signal processing techniques commonly used for broken bars detection on induction motors. Single Stator Current's FFT," IEEE Trans. Instrum. Meas., vol. 64, no. 11, pp. 3137-3146, Nov. 2015. 
Journal of Electronics and Informatics (2021)

Vol.03/ No.01

Pages: 61-76

https://www.irojournals.com/iroei/

DOI: https://doi.org/10.36548/jei.2021.1.006

[5] M. J. Picazo-Rodenas, J. Antonino-Daviu, V. Climente-Alarcon, R. Royo-Pastor, and A. Mota-Villar, "Combination of Noninvasive Approaches for General Assessment of Induction Motors,” IEEE Trans. Ind. Appl., vol. 51, no. 3, pp. 2172-2180, May 2015.

[6] S. Karmakar, S. Chattopadhyay, M. Mitra, and S. Sengupta, Induction Motor Fault Diagnosis. Singapore: Springer Singapore, 2016.

[7] D. Granda, W. G. Aguilar, D. Arcos-Aviles, and D. Sotomayor, "Broken Bar Diagnosis for Squirrel Cage Induction Motors Using Frequency Analysis Based on MCSA and Continuous Wavelet Transform," Math. Comput. Appl., vol. 22, no. 2, p. 30, Apr. 2017.

[8] D. Sotomayor, S. Castellanos, D. Arcos-Aviles, and D. Benitez, "A computer-aided test bench system for teaching and research on fault detection in three-phase induction motors," in IEEE 37th Central American and Panama Convention (CONCAPAN XXXVII), Managua, Nicaragua, Nov. 2017, pp. 1-6.

[9] M. R. Mehrjou, N. Mariun, M. Karami, S. B. M. Noor, S. Zolfaghari, N. Misron, M. Z. A. A. Kadir, M. A. M. Radzi, and M. H. Marhaban, "Wavelet-Based Analysis of MCSA for Fault Detection in Electrical Machine," in Wavelet Transform and Some of Its Real-World Applications, InTech, Dec. 2015.

[10] Batool, M., \& Ahmad, A. (2013). Mathematical modeling and speed torque analysis of three phase squirrel cage induction motor using matlab simulink for electrical machines laboratory. International Electrical Engineering Journal (IEEJ), 4(1), 880-889.

[11] Leedy, A. W. (2013). Simulink/matlab dynamic induction motor model for use as a tteaching and research tool. International Journal of Soft Computing and Engineering (IJSCE), 3(4), 102-107.

[12] Mal, K., Hussain, I., Chowdhry, B. S., \& Memon, T. D. (2020). Extended kalman filter for estimation of contact forces at wheel-rail interface. 3C Tecnología. Glosas de innovación aplicadas a la pyme. Edición Especial, Abril 2020, 279-301.

[13] Mortazavizadeh, S., \& Mousavi, S. (2014). A review on condition monitoring and diagnostic techniques of rotating electrical machines. Physical Science International Journal, $4(3), 310$. 
Journal of Electronics and Informatics (2021)

Vol.03/ No.01

Pages: 61-76

https://www.irojournals.com/iroei/

DOI: https://doi.org/10.36548/jei.2021.1.006

[14] Pandey, K., Zope, P., \& Suralkar, S. (2012). Review on fault diagnosis in three-phase induction motor. In MEDHA-2012, Proceedings published by International Journal of Computer Applications (IJCA).

[15] Sharma, A., Chatterji, S., Mathew, L., \& Khan, M. J. (2015). A Review of Fault Diagnostic and Monitoring Schemes of Induction Motors. International Journal for Research in Applied Science and Engineering Technology (IJRASET), 3(4).

[16] Shi, P., Chen, Z., Vagapov, Y., Davydova, A., \& Lupin, S. (2014). Broken bar fault diagnosis for induction machines under load variation condition using discrete wavelet transform. Proceedings of IEEE East-West Design \& Test Symposium (EWDTS 2014), Kiev, Ukraine.

[17] Siddiqui, K. M., Sahay, K., \& Giri, V. (2014). Health monitoring and fault diagnosis in induction motor-a review. International Journal of Advanced Research in Electrical, Electronics and Instrumentation Engineering, 3(1), 6549-6565.

[18] Soother, D. K., \& Daudpoto, J. (2019). A brief review of condition monitoring techniques for the induction motor. Transactions of the Canadian Society for Mechanical Engineering, 43(4), 499-508.

[19] Refaat, S.S., Abu-Rub, H., Saad, M.S., Aboul-Zahab, E.M., Iqbal, A., "Detection, diagnoses and discrimination of stator turn-to-turn fault and unbalanced supply voltage fault for three-phase induction motors," Power and Energy (PECon), 2012 IEEE International Conference on 2-5 Dec. 2012, pp.910-915.

[20] Mehala, Neelam, and Ratna Dahiya. "Motor current signature analysis and its applications in induction motor fault diagnosis." International journal of systems applications, engineering \& development vol.2, no. 1, pp.29-35, 2007.

[21] Dash, Sourabh, and Venkat Venkatasubramanian. "Challenges in the industrial applications of fault diagnostic systems." Computers \& Chemical Engineering, 24.2 (2000): pp. 785-791.

[22] Gao, Z., Cecati, C., \& Ding, S. X. (2015). A survey of fault diagnosis and fault-tolerant techniques-Part I: Fault diagnosis with model-based and signal-based approaches. IEEE Transactions on Industrial Electronics, 62(6), 3757-3767. 
Journal of Electronics and Informatics (2021)

Vol.03/ No.01

Pages: 61-76

https://www.irojournals.com/iroei/

DOI: https://doi.org/10.36548/jei.2021.1.006

[23] El Bouchikhi, E. H., Choqueuse, V., \& Benbouzid, M. (2015). Induction machine diagnosis using stator current advanced signal processing. International Journal on Energy Conversion, 3(3), 76-87.

[24] Soother, D. K., Daudpoto, J., \& Shaikh, A. (2018). Vibration measurement system for the low power induction motor. Engineering Science And Technology International Research Journal, 2(4), 53-57.

[25] Ujjan, S. M., Kalwar, I. H., Chowdhry, B. S., Memon, T. D., \& Soother, D. K. (2020). Adhesion level identification in wheel-rail contact using deep neural networks. 3C Tecnología. Glosas de innovación aplicadas a la pyme. Edición Especial, Abril 2020, 217-231.

[26] K. Gyftakis, J. Antonino-Daviu, R. Garcia-Hernandez, M. McCulloch, D. Howey, A. Cardoso, Comparative Experimental Investigation of the Broken Bar Fault Detectability in Induction Motors, IEEE Transactions on Industry Applications, 10 (2015) 1-1.

[27] M. Riera-Guasp, M. Pineda-Sanchez, J. Perez-Cruz, R. Puche-Panadero, J. Roger-Folch, J.A. Antonino-Daviu, Diagnosis of induction motor faults via gabor analysis of the current in transient regime, IEEE Transactions on Instrumentation and Measurement, 61 (2012) 1583-1596. 